Vol. 4, No. 01; 2021

ISSN: 2581-4664

\title{
THE EFFECT OF SERVICE QUALITY ON DELIVERY SATISFACTION IN ONLINE SHOPPING: A CASE STUDY OF RAMKHAMHAENG UNIVERSITY LECTURERS, BANGKOK, THAILAND
}

\author{
Nopphong Kerdngern ${ }^{1}$, Peter Rungrueangkan ${ }^{1}$, Sutthathip Kamthornphiphatthanakul ${ }^{1}$ and Narintorn \\ Somthong ${ }^{2}$ \\ ${ }^{1}$ Department of MBA Logistics and Supply Chain Management, Ramkhamhaeng University, Bangkok, Thailand \\ ${ }^{2}$ Department of Accounting Management, Ramkhamhaeng University, Bangkok, Thailand
} http://doi.org/10.35409/IJBMER.2021.3224

\begin{abstract}
The aim of this study was to studying in the level of delivery satisfaction (DS), the effect of personal factors and service quality (SQ) on delivery satisfaction in online shopping with the empirical data. The quantitative research was used in this study by survey research that was used collect sample data from 92 Ramkhamhaeng University lecturers. The data analyses were conducted by t-Test, One Way ANOVA and Multiple Regression Analysis (MRA). The results showed that Ramkhamhaeng University lecturers have highest satisfaction. And most of personal factors and service quality factors have effect on delivery satisfaction. Moreover, the results found that the 3 factors of service quality such as tangibles factor, assurance factor and empathy factor have effect on satisfaction (Sig. $=0.05$ ) except for the reliability factor and responsiveness factor have not effect on delivery satisfaction.
\end{abstract}

Keyword: Service Quality, Delivery Satisfaction, Online Shopping.

\section{INTRODUCTION}

Nowadays, the customers are rapidly increasing and adopting online shopping day by day due to busy and complex lifestyle that affect behavior in using the internet to buy goods and services online. The 4 factors that support the online shopping growth which are 1) Government Supporting and Promotion 2) Online Sale and Services channels 3) Growth of Online market and 4) Growth of Online Business foreign investors ( Watcharaphon Jiangkong, 2017) E-Commerce or Online Shopping has to play an important role in promoting high-value and fast-growing economies. According to AliResearch forecasts report that shown the value of online business operations globally will have a growth higher than $27.30 \%$ in 2018 . Thailand is considered the country with the highest growth rate of B2C (Business to Consumer) ranked No. 1 in ASEAN that the survey results of Thailand's e-commerce growth continuously between $8-10 \%$ per year. The value of the online business in Thailand in 2017 was 2.7 trillion baht and is expected to total increase of approximately 3.1 trillion baht in 2018 (ETDA, 2019). 


\section{International Journal of Business Management and Economic Review}

Vol. 4, No. 01; 2021

ISSN: 2581-4664

For the development of online shopping, many sellers need to adjust with changeable market requirements. To gain competitive advantage, online sellers must understand the importance of customer satisfaction. The customer satisfaction is the key to building profitable relationships with consumers to keeping and growing consumers and reaping their customer lifetime value (Kotler et al., 2011). The customer satisfaction is becoming more and more prominent that through high quality products and services providing value for money to the customer are seen as essential for long-term survival let alone long-term success (Wisniewski and Donnelly, 1996). Service Quality is the basis of service that must meet the service needs of customers. Which can be said that the quality of service. It is like a guarantee of business success (Liu and Xie, 2013). According to the study, the researcher found that the quality of service factors affected the satisfaction of the service such as the study of Huang, Yu-Kai; Chong Keng Li, Dalin and ChiaYi Shien. (2009) found that the quality of service affects the satisfaction of customers which corresponds to the study of which can conclude that the research quality of service factors affect the enhancement of service users' satisfaction.

Another online shopping problem that most people complain and maintain customer satisfaction is poor delivery service that result in product arrival takes too long or even damaged. Delivery service is absolutely important in e-commerce, because it is the last stage of the order fulfillment process and from the consumers' point of view, the most critical. Timely and reliable delivery must be the number one priority and is crucial to the success of every online shop on the planet (Chonthicha Kingchampa, 2015). There are many deliverer in Thailand such as; Thailand Post, Kerry Express, LALAMOVE, NIM Express, TNT, Lineman, Niko's Logistics, DHL, Best Express Thailand, CJ Korea Exoress, SCG Express, Speed D, Ninja- van, Alpha, GrabBike and Skootar, etc.

Service quality has become a very popular area of academic investigation and is recognized as a key factor in differentiating service providers and building competitive advantage (Ennew and Binks, 1996). More and more companies try to achieve successful service quality to increase customer's satisfaction, higher profit, and motivated work force and enhance market shares in different industries. Service quality can be evaluated by comparing consumer expectations with their experiences of actual service provision (Oliver, 1980). Parasuraman et al., (1988) indicated "SERVQUAL" to measure service quality by calculating difference in gap scores between corresponding "Satisfaction = Perception - Expectation" across five dimensions which are tangibles, reliability, responsiveness, assurance and empathy. Thus, the customer satisfaction is the relative level of their expectation and perceived performance. In this study, the researcher was to studying in the level of delivery satisfaction (DS), the effect of personal factors and service quality (SQ) in terms of tangibles, reliability, responsiveness, assurance and empathy on delivery satisfaction in online shopping of Ramkhamhaeng University lecturers, Bangkok, Thailand.

\section{LITERATURE REVIEW}

\section{Service Quality}

Service quality is the foundation of services marketing that associated with an attitude representing a long-term, evaluation, customer satisfaction and transaction judgment (Cronin and Taylore, 1994). Service quality was defined as an overall judgment or attitude towards service and generally accepted as antecedent of overall customer satisfaction (Zeithaml and 


\section{International Journal of Business Management and Economic Review}

Vol. 4, No. 01; 2021

ISSN: 2581-4664

Parasuraman, 1996). Parasuraman et al., (1988) indicated that the service quality is more than product quality because service is intangible, heterogeneous, and production is inseparable from consumption. The awareness in service quality has been powerful in contributing significantly to the expansion of general services marketing field. There are 5 dimensions of service quality characteristics, namely: Tangibles or physical evidences are the appearance of physical facilities, equipment, personnel and communication materials. Reliability is the ability to perform the promised service dependably and accurately. Responsiveness is the willingness to help customers and provide prompt services. Assurance is the knowledge and courtesy of employees and their ability to convey trust and confidence. Empathy is the caring, individualized attention the firms provide the customers (Parasuraman et al., 1988).

\section{Delivery Satisfaction}

Delivery Satisfaction is the satisfaction's customer in deliver products to customer. Customer satisfaction is used in the whole business that explain about a measurement of the kind of products and services to meet customer's expectation. Customer satisfaction is defined as an overall evaluation based on the total purchase and consumption experience with the good or service over time (Fornell, Johnson, Anderson, Cha and Bryant, 1996). Customer satisfaction is the major cognitive and affective reaction to a service incident and ascertains the expectation of the customer. Actionable information on how to make customers further satisfied is therefore, a crucial outcome (Oliver 1999) The factors that affect customer satisfaction are price, timeliness of deliveries, completeness of deliveries (productive capacity to realization of ordering products), promptness of deliveries, accurately invoiced, accurately of deliveries, flexibility of deliveries, keeping the commitment (conditions of agreement), transportations conditions, terminal conditions (theft protection, work organization, furnishings, etc.) and complexity of services (Kusnierz and Gajewska, 2014)

\section{Related research}

The delivering high quality service that will in turn result in satisfied customers. From various research, many researcher have studied in the effect of service quality on customer satisfaction, follow: Lien. , Che-Hui, Wen, and Wu (2011) studied the relationship of electronic service quality and Taiwanese online shopping satisfaction. The result found that the quality of electronic services has a positive influence on the perceived value and satisfaction of users. Retnaningsih (2013) examined the relationship between the quality of service and the satisfaction of airline users. Lion Airlines in Surabaya. The results of the research show that the quality of service is related to the satisfaction of users.

Haryono, Suharyono, Fauzi and Suyadi (2015) studied the impact of service quality on the satisfaction of users of Yogyakarta International Airlines in Indonesia. The result found that service quality influenced customer satisfaction. Chung, Cho, and Chung (2016) studied the online shopping customers in Korea that found the quality of service in delivering products have a positive effect on customer satisfaction. Otsetova (2017) studied the relationship between the quality of transportation services and customer satisfaction in the shipping service sector which concludes that high quality service can maintain customer satisfaction.

\section{Conceptual framework}


Vol. 4, No. 01; 2021

ISSN: 2581-4664

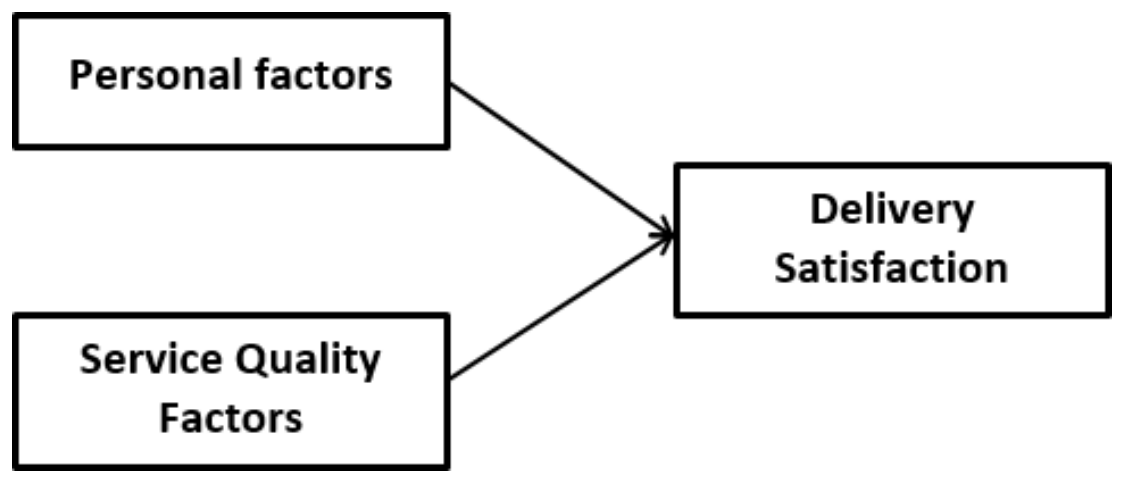

\section{Research Hypothesis}

1. Ramkhamhaeng University lecturers have the high level of delivery satisfaction in online shopping.

2. Personal factors have effect on delivery satisfaction in online shopping of Ramkhamhaeng University lecturers.

3. Service Quality factors have effect on delivery satisfaction in online shopping of Ramkhamhaeng University lecturers.

\section{Research Methodology}

This empirical research is quantitative that was carried out with a sample of 92 Ramkhamhaeng University lecturers using a questionnaire that was using the accidental random sampling techniques and the proposed t-Test, One Way ANOVA and Multiple Regression Analysis (MRA). The research questionnaire contains three sections. The first section is the demographics of the respondents. The second section deals with the Service Quality, and the third section concerns the Delivery Satisfaction. The questionnaire questions in sections 2 and 3 are of the five-point Likert-type scale questions.

Prior to the data collection, the questionnaire questions were reviewed by a panel of three qualified experts and have satisfied the content validity requirements with the questions' index of item-objective congruence (IOC) in the range of 0.6-1.0. According to Rovinelli and Hambleton (1976), the IOC greater than 0.5 is regarded as statistically significant. The questionnaire questions were then trialed with a group of 30 Ramkhamhaeng University lecturers to determine the internal consistency reliability. Cronbach's alpha coefficients of the questionnaire were 0.760.8 . According to Hee (2014), the alpha coefficient greater than or equal to 0.6 is regarded as statistically significant.

\section{RESEARCH RESULT}




\section{International Journal of Business Management and Economic Review}

Vol. 4, No. 01; 2021

ISSN: 2581-4664

This result that shows the samples were 15 males and 77 female between the ages of 36 and 45 years. The levels of education included master's degree (91\%) in the lecturer position. The length of work experience encompassed less than 1 year (13\%), 1-4 years $(9 \%), 5-10$ years $(62 \%)$, and more than 10 years

(16\%). The levels of income included THB 20,000-40,000 (52\%), THB 40,001-60,000 (41\%), and above

THB 60,000 (7\%), where 1 USD is equal to THB 31 .

\section{Level of delivery satisfaction.}

For the result in Table 1 that show Ramkhamhaeng University lecturers are highest satisfy in all delivery factors. Furthermore, result is showing the completeness of delivery factor has highest satisfy in deliverer factors of this study.

Table 1: The results provided by the level of delivery satisfaction in online shopping of Ramkhamhaeng University lecturers.

\begin{tabular}{|c|c|c|c|}
\hline Delivery Factors & Mean & SD. & Satisfaction Level \\
\hline Pricing & 4.37 & 0.64 & Highest \\
\hline Timeliness of deliveries & 4.47 & 0.74 & Highest \\
\hline Completeness of deliveries & 4.52 & 0.67 & Highest \\
\hline Accurately of deliveries & 4.49 & 0.71 & Highest \\
\hline Characteristics of deliverer & 4.39 & 0.91 & Highest \\
\hline Delivery Satisfaction & 4.31 & 0.71 & Highest \\
\hline
\end{tabular}

\section{Effect of Personal Factors on Delivery Satisfaction.}

For the result in Table 2 that show the personal factors as: gender has not effect on delivery satisfaction in online shopping of Ramkhamhaeng University lecturers.

Table 2: The results of $t$-Test provided by the effect of Gender Factors on Delivery Satisfaction in online shopping of Ramkhamhaeng University lecturers.

\begin{tabular}{|c|c|c|c|c|}
\hline Gender & Frequency & Mean & Std. Deviation & Sig. \\
\cline { 1 - 4 } Male & 15 & 4.60 & 0.50 & \multirow{2}{*}{0.09} \\
\cline { 1 - 4 } Female & 77 & 4.26 & 0.74 & \\
\hline
\end{tabular}

For the result in Table 3 that show the personal factors as: Age, Education level, Academic Positions, Experience and monthly income have effect on delivery satisfaction in online shopping of Ramkhamhaeng University lecturers.

Table 3: The results of ANOVA provided by the effect of Personal Factors on Delivery Satisfaction in online shopping of Ramkhamhaeng University lecturers. 


\section{International Journal of Business Management and Economic Review}

Vol. 4, No. 01; 2021

ISSN: 2581-4664

\begin{tabular}{|c|c|c|c|c|}
\hline Factor & SS & df & F & Sig. \\
\hline Age & 57.68 & 91 & 33.91 & 0.00 \\
\hline Education level & 17.25 & 91 & 2.60 & 0.02 \\
\hline Academic Positions & 33.68 & 91 & 19.93 & 0.00 \\
\hline Experiences & 83.16 & 91 & 18.22 & 0.00 \\
\hline Monthly Income & 35.00 & 91 & 8.12 & 0.00 \\
\hline
\end{tabular}

\section{Effect of Service Quality Factors on Delivery Satisfaction.}

For the result in Table 4 that show the service quality factors as: Tangible, Assurance and Empathy have effect on delivery satisfaction in online shopping of Ramkhamhaeng University lecturers, except for the Reliability and Responsiveness that have not effect on delivery satisfaction in online shopping of Ramkhamhaeng University lecturers.

Table 4: The results of Multiple Regression Analysis (MRA) provided by the effect of Service Quality Factors on Delivery Satisfaction in online shopping of Ramkhamhaeng University lecturers.

\begin{tabular}{|c|c|c|c|c|}
\hline \multirow{2}{*}{ Factor } & \multicolumn{4}{|c|}{ Delivery Satisfaction } \\
\cline { 2 - 5 } & $\mathbf{B}$ & $\boldsymbol{\beta}$ & $\mathbf{t}$ & Sig. \\
\hline Constant & 1.55 & & 2.94 & 0.00 \\
\hline Tangibles & 0.26 & 0.28 & 2.41 & 0.01 \\
\hline Reliability & -0.58 & -0.49 & -1.83 & 0.07 \\
\hline Responsiveness & -0.22 & -0.19 & -0.60 & 0.54 \\
\hline Assurance & 0.65 & 0.68 & 2.00 & 0.04 \\
\hline Empathy & 0.53 & 0.50 & 2.35 & 0.02 \\
\hline
\end{tabular}

Remark; $R^{2}=0.44, A R=0.41, F=13.85, p$ value $<0.05$

\section{CONCLUSION}

This research was to studying in the level of delivery satisfaction (DS), the effect of personal factors and service quality (SQ) on delivery satisfaction in online shopping of Ramkhamhaeng University lecturers, Bangkok, Thailand. In the study, the quantitative research was carried out with a sample of 92 Ramkhamhaeng University lecturers using a questionnaire that analyzed by t-Test, ANOVA and MRA. The results that show Ramkhamhaeng University lecturers are highest satisfy in all delivery factors indicating that the lecturers attached the greatest 


\section{International Journal of Business Management and Economic Review}

Vol. 4, No. 01; 2021

ISSN: 2581-4664

significance to this delivery service that consistent with Ratthanan Pukpakdee (2014) and Methawat Watchachathai and Asawin Saengpikun (2018). And the finding of personal factors show that Age, Education level, Academic Positions, Experience and monthly income have effect on delivery satisfaction in online shopping of Ramkhamhaeng University lecturers (Pennapa Charatphan , 2014; Kanyakan Chan Liam and Phat Phisitkasem, 2018) except for gender factor (Pornprapa Chai-Anukul, 2014; Siriwimon Kamwong, 2016).

From the results of the Service Quality factors effect on delivery satisfaction show that 3 factors (Tangible, Assurance and Empathy) have effect on delivery satisfaction in online shopping of Ramkhamhaeng University lecturers. This is consistent with Hussain and Hussain (2015) who documented that shown service quality had a significant positive effect on satisfaction of Dubai airline passengers.

However, the results the Service Quality factors show that 2 factors Reliability and Responsiveness have not effect on delivery satisfaction in online shopping of Ramkhamhaeng University lecturers. This may be caused by the deliverer have not communication skills to get more reliability from the customers and failing to meet the customer expectations that consistent with Panida Petcharat. (2013), Sansani Siphimrak (2 013 ) and Alisa Thitmanakul. (2015).

\section{Certification of human research ethics and academic ethics}

This study has been certified for research ethics from the Ethics Subcommittee Of human subjects (Project Code RU-HS-RESC xd-0064/62) and similarity index found 0.00\%.

\section{REFERENCES}

Alisa Thitimanakul. (2015). Satisfaction in service quality of consumers. That affects the change of mobile network service providers with the same number rights In Bangkok and perimeter. Independent Study, Master Degree, Thammasat University, Bangkok

Christine T. Ennew, Martin R. Binks. (1996). The Impact of Service Quality and Service Characteristics on Customer Retention: Small Businesses and their Banks in the UK1. British Journal of Management 7(3), 219-230.

Cholthicha Kingchampa. (2015). Factors Affecting Freight Carriers Behavior in Wellgrow Industrial Estate, Chachoengsao Province Independent study Logistics and Supply Chain Management Program Faculty of Business Administration Sriprathum University Chon buri Campus

Cronin, J. J., \& Taylor, S. A. (1994). SERVPERF versus SERVQUAL: Reconciling performance-based and perceptions-minus-expectations measurement of service quality. Journal of Marketing, 58(1), 125- 131.

Electronic Transactions Development Agency (Public Organization) (2018) Report of ECommerce Survey in Thailand 2018, Ministry of Digital Economy and Society, Bangkok Fornell, C., Johnson, M.D., Anderson, E.W., Cha, J. and Bryant, B.E. (1996), "The American customer satisfaction index: nature, purpose, and findings", Journal of Marketing, 60(4), 7-18. Haryono, S., Suharyono, AchmadFauzi D.H., Suyadi, I, (2015). The Effects of Service Quality on Customer

Satisfaction, Customer Delight, Trust, Repurchase Intention, and Word of Mouth. European Journal of Business and Management, 7(12) 


\section{International Journal of Business Management and Economic Review}

Vol. 4, No. 01; 2021

ISSN: 2581-4664

Huang, Yu-Kai; Chong Keng Li, Dalin, Chia-Yi Shien. (2009) . The Effect of Airline Service Quality on Passengers' Behavioural Intentions Using SERVQUAL Scores: A TAIWAN Case Study, Journal of the Eastern Asia Society for Transportation Studies, Vol.8.

Hussain, R., Nasser, A.A., \& Hussain, Y.K. (2015). Service quality and customer satisfaction of a UAE- based airline: An empirical investigation. Journal of Air Transport Management, 42(1), $167-175$.

Hee OC. (2014). Validity and reliability of the customer-oriented behavior scale in the health tourism hospitals in Malaysia. Int J Caring Sci 7(3): 771-775.

Ji Bok Chung, B. C. C., Yong Sang Cho,Lak Chae Chung. (2016). Service quality of online grocery shopping in Korean local regions. Journal of Distribution Science

Karim, F., (2012). Customer Satisfaction and Awareness of Islamic Banking Produscts and Services in Pakistan, Interdisiplinary Journal of Contemporaray Research in Business, Vol.4, No. 4.

Kanyakanchan Liam and Phatphisit Kasem. (2018). Factors affecting the satisfaction of the use of the Thai postal service. Rangsit University branch Journal of Rangsit Graduate Studies in Business and Social Sciences Rangsit University. 4 (2), 352-364.

Kotler P., Armstrong G., Saunders J., Wong V. (2011). Marketing. European textbook, PWE, Warsaw, 128. Lien, Che-Hui, Miin-Jye Wen, Chung-Cheng Wu, (2011). Investigating the Relationships among E-Service Quality, Perceived Value, Satisfaction, and Behavioral Intentions in Taiwanese Online Shopping Asia Pacific Management Review 16(3) 211-223

Liu, W., H., and Xie, D. (2013) Quality decision of the logistics service supply chain with service quality guarantee. International Journal of Production Research, 51 (5), 1618-1634.

Malgorzata Lisinska-Kusnierz and Teresa Gajewska. (2014) Customer Satisfaction with the Quality of the Logistics Services. Scientific Journal of Logistics, 10 (1), 13-19

Methawachat Thai and Atsawang Saengpikun. (2018). Service quality factors affecting the satisfaction of foreign tourists. When using the services of the Middle East airline. Journal of academic conferences and national research presentations, 3rd Ratchathani academic, 40-54.

Maslow, A. (1970). Motivation and Personality. New York: Harper and Row Publishers. Oliver, R.L. (1999) Whence Consumer Loyalty. Journal of Marketing, 63, 33-34.

Otsetova, A. (2017). Relationship between logistics service quality, customer satisfaction and loyalty in curier services industry. Management and Education, 13.

Parasuraman A, Zeithaml A, Valarie L.L, and Berry L.L. (1988). SERVQUAL; A Multiple-Item Scale for Measuring Consumer Perceptions of Service Quality.Journal of Retailing, 64, p.12-40. Panida Petcharat. (2013). Service quality that affects satisfaction. Of the taxpayer, Nakhon Ratchasima Area Revenue Office 2. Independent Study, Master Degree, Rajamangala University of Technology Isan, Khon Kaen

Pennapa Charasphan. (2014). Customer satisfaction with service quality. Of Genet Mobile Service Center, Chanthaburi. Master Thesis, Burapha University, Chon Buri

Pornprapa Chai-Anukul. (2014). Service quality of tourist attractions that affects the satisfaction of Thai tourists In Suan Phueng District, Ratchaburi Province Independent research Master of Business Administration. Pathum Thani: Thanyaburi University of Technology, Pathum Thani 


\section{International Journal of Business Management and Economic Review}

Vol. 4, No. 01; 2021

ISSN: 2581-4664

Ratthanan Pukpakdee. (2014). Satisfaction of Thai service users with Thai Airways. Independent research Degree: Master of Business Administration, Bangkok University, Bangkok

Retnaningsih, Wiwik. (2013). Effect on the Quality of Customer Satisfaction of Lion Air Airline in Surabaya City,International Journal of Business and Management Invention, 2I (8), 16-25.

Richard L. Oliver. (1980). A Cognitive Model of the Antecedents and Consequences of Satisfaction

Decisions, Journal of Marketing Research 17(4) (Nov., 1980), 460-469

Rovinelli RJ and Hambleton RK. (1976). On the use of content specialists in the assessment of criterion- referenced test item validity. Paper presented at the Annual Meeting of the American Educational Research Association 60th, San Francisco, California.

Sansani Si Phim. (2013). Satisfaction of tourists with the quality of service of international hotel chains at

the level of 5 - 5 stars in Bangkok. Master of Business Administration Thesis: Master of Business University. Nonthaburi

Watcharaporn Jiang of. (2017) Factors Affecting Online Shopping with Focus on Factors of Receiving Channels, Master of Science. Burapa University. Chon Buri.

Wisniewski, M., \& Donnelly, M. (1996). Measuring service quality in the public sector: the potential for SERVQUAL. Total Quality Management and Business Excellence, 7(4), 357-365.

Zeithaml, V. A., Berry, L.L. \& Parasuraman, A. (1996). The behavioural consequences of service quality.

Journal of Marketing Management, 60, 31-46. 